\title{
Biolaw: Cracking the Code
}

\author{
Jim Chen ${ }^{*}$
}

The neologism biolaw describes all areas of law informed by the life sciences. Health law, bioethics, environmental law, natural resources law, agricultural law, food and drug law, biotechnology, law and neuroscience, law and behavioral psychology, and evolutionary analysis of law all share a common scientific core. Lawyers and legal scholars too often address these topics in isolation. This piecemeal approach undermines the scientific cohesion that connects these areas of legal practice and theory. The common core, of course, is biology - all of the life sciences, unified in pursuit of subjects considered worthy of legal attention. This essay attempts, in the spirit of Edward O. Wilson's Consilience: The Unity of Knowledge, ${ }^{1}$ to define biolaw as the field of law and the life sciences in its entirety.

Historian David Christian has argued "that the appropriate time scale for the study of history may be the whole of time."2 Likewise, the "substantive scale on which law should be studied, taught, and learned is the entirety of human experience." 3 A comprehensive approach to biolaw treats law and the life sciences as related disciplines, as components of a unified, consilient body of knowledge. Mindful that knowledge comprises not only a "domain" consisting of "a set of symbolic rules and procedures" but also a "field" consisting of "all the individuals who act as gatekeepers to the domain," I shall describe not only the content of biolaw, but also its place within the contemporary legal academy. With any luck, this description of biolaw from a "far-overhead vantage point" will provide "topsight" into the relationship between law and the life sciences and

\footnotetext{
* Dean and Professor of Law, University of Louisville. I thank Katharine Van Tassel and Antigone Nounou for helpful comments.

1. Edward O. Wilson, CONSILIENCE: The Unity OF KNOWLEdGE (1998).

2. David Christian, The Case for “Big History," 2 J. WORLD HisT. 223, 223 (1991).

3. Jim Chen, Introduction, The Pragmatic Ecologist: Environmental Protection as a Jurisdynamic Experience, 87 MINN. L. REV. 847, 849 (2003).

4. Mihaly CSIKSZENTMihalyi, CREATIVITy: Flow AND THE PSyCHOlOGy OF Discovery AND INVENTION 27-28 (1996).
} 
thereby generate "a bird's eye view that reveals the whole - the big picture; how the parts fit together."

Part I of this essay will provide a brief guide to the various branches of biolaw. Part II offers some thoughts on the intellectual significance of treating biolaw as a scientifically coherent enterprise.

\section{BIOLAW: A JURISONOMY}

Linnaean taxonomy classifies the members of the biosphere according to a hierarchical set of categories: kingdom, phylum, class, order, family, genus, species (readily committed to mnemonics such as "kings play chess on fancy glass stools"). Like its biological counterpart, biolaw lends itself to a systematic form of classification - a jurisonomy, if you will, by analogy to the better established neologism, folksonomy (folk + taxonomy). Five basic dichotomies distinguish the various branches of biolaw: legal analysis of biology versus biological analysis of law, ecolaw versus anthropolaw (oíko $\varsigma$ versus óv $\theta \rho \omega \pi \mathrm{oc}$ ), conservation versus exploitation, greens versus browns, and conventional versus transgenic biotechnology.

\section{A. Legal Analysis of Biology Versus Biological Analysis of Law}

This is perhaps the most fundamental divide of all. Entire bodies of law are devoted to biological subject matter. Health law, environmental law, and food and drug law are perhaps the largest categories. Agricultural law and the law of natural resources (especially forestry and fisheries) remind us that the law pays special attention to extraction industries. Bioethics and biotechnology law patrol the frontiers where human ingenuity collides with boundaries set by natural genomes and social mores. All of these areas derive their intellectual coherence, and their legitimacy, from the law itself. The United States Code, after all, includes the National Environmental Policy Act, as enacted January 1, 1970, ${ }^{6}$ and as subsequently amended. The vast majority of biolaw's practitioners devote themselves to some variation or another on this theme. "Legal analysis of biology" accounts for most of the intellectual biomass in biolaw. The social triumph of this branch of the discipline can be measured with a solitary but singularly impressive statistic: the first seventy-eight years of

5. David Gelernter, Mirror Worlds or the Day Software Puts the Universe in a SHOEBOX ... HOW IT WiLl HAPPEN AND What IT WILl MEAN 52 (1991) (emphasis omitted); see also $i d$. at 52-53 (describing topsight as "the quality that distinguishes genius in any field" and "the most precious intellectual commodity known to man" (emphasis omitted)).

6. Pub. L. No. 91-190, 83 Stat. 852 (codified as amended at 42 U.S.C. $\S \S 4321-4370 d$ (2000)). 
systematic food and drug regulation in the United States coincided with a shocking increase of twenty-six years in life expectancy, an actuarial leap forward unprecedented in human history and, at least in the developed world, unlikely to be duplicated. ${ }^{7}$

But a growing body of legal scholarship subjects problems from all aspects of law to analysis that is either explicitly biological or at least strongly influenced by the life sciences. Entire careers in law teaching now hinge on the application of neuroscience, behavioral psychology, and evolutionary biology to subjects as varied as family law, criminal law, and torts. ${ }^{8}$ To the extent that "behavioral economics" is merely a left-of-center label for "evolutionary biology" or even "sociobiology," a field whose faint (and fallacious) association with social Darwinism is anathema to the legal academy's dominant culture, "biological analysis of law" arguably embraces the entire post-Chicago law and economics movement. For instance, the entire roster of shortcomings in environmental protection and risk regulation, ${ }^{9}$ especially mistakes in judgment traceable to the overvaluation of salient evidence, ${ }^{10}$ has a biological basis. If this broad definition takes hold, biological analysis of law might already command a greater intellectual profile than its more practice-oriented subdisciplines among established areas of law devoted to regulating living things and the life sciences.

\section{B. Ecolaw Versus Anthropolaw}

An essay designed to explain a neologism might be well advised to avoid stacking further neologisms. But the difference between the ancient Greek words oíko (meaning house) and óv $\theta \rho \omega \pi \mathrm{s}$ (meaning human being) facilitates a convenient and useful way of distinguishing between branches of biolaw. oíkos supplies the English root eco-, which Ernst Haeckel (using

7. See Peter Barton Hutt, Food and Drug Law: A Strong and Continuing Tradition, 37 FooD DRUG CoSM. L.J. 123, 125 (1982).

8. See generally, e.g., Owen D. Jones \& Timothy H. Goldsmith, Law and Behavioral Biology, 105 COLUM. L. REV. 405 (2005).

9. See generally, e.g., Howard Margolis, DeAling With Risk: Why the Public and the EXPERTS DisAGREE ON ENVIRONMENTAL ISSUES (1996); Timur Kuran \& Cass R. Sunstein, Availability Cascades and Risk Regulation, 51 STAN. L. Rev. 683 (1999); Cass R. Sunstein, Cognition and CostBenefit Analysis, 29 J. Legal Stud. 1059 (2000); Cass R. Sunstein, Probability Neglect: Emotions, Worst Cases, and Law, 112 YALE L.J. 61 (2002); Cass R. Sunstein, The Laws of Fear, 115 HARV. L. REV. 1119 (2002) (reviewing PAUl SLOVIC, THE PERCEPTION OF RISK (2000)).

10. See Richard NisBetT \& LeE Ross, Human InFERENCE: STRATEGIES AND SHORTCOMINGS OF Social Judgment 123 (1980); Matthew Rabin, Psychology and Economics, 36 J. ECON. LiT. 11, 30-31 (1998); Amos Tversky \& Daniel Kahneman, Judgment under Uncertainty: Heuristics and Biases, 185 SCIENCE 1124, 1124 (1974). 
the German analogue öko-) used to coin the term ecology. ${ }^{11}$ Av $\theta \rho \omega \pi \mathrm{o}$, for its part, is the origin of words such as anthropology, misanthrope, and anthropocentric. Although the difference is often one of perspective rather than substance, ecological and anthropocentric approaches to biolaw seem to rest on divergent, and sometimes even contradictory, ethical premises. For this reason alone, the distinction is worth observing.

Consider the problem of regulating airborne lead. ${ }^{12}$ From ecolaw's point of view, removing lead-based additives from gasoline is a straightforward application of the Clean Air Act, one of the broadest environmental statutes designed to guarantee the integrity of a basic medium, the terrestrial atmosphere. By contrast, anthropolaw would regard the problem of leaded gasoline as one of public health and perhaps also of social justice (insofar as the most vulnerable victims of lead poisoning tend to be young, poor, and nonwhite). Few, if any, practitioners or scholars of environmental law would view the problem as strictly one of environmental protection, or strictly one of public health. Nevertheless, drawing the distinction forces us to decide, at least as a matter of initial ethical principles, whether human health or a less anthropocentric notion of "deep green" is paramount.

Indeed, on some occasions - for instance, the introduction of the Nile

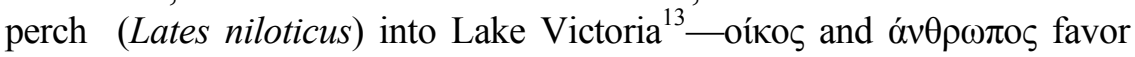
radically different outcomes. The ecological loss of biological diversity in "Darwin's Dreampond," estimated as the extinction of several hundred endemic cichlids, is simply incommensurable. By contrast, an anthropocentric analysis would give at least some weight to the economic value of Lake Victoria's Nile perch fishery and of sport fishing tourism to the lake.

11. See Stephen Jay Gould, Ontogeny and Phylogeny 76 n.* (1977). Haeckel is also credited with coining the phrase, "[o]ntogeny ... recapitulate[es] ... phylogeny" —or, in lay terms, the notion that the life history of any individual organism replays the entire evolutionary history of that organism's species. Id. at 76 .

12. See Clean Air Act, § 109(b)(1), 42 U.S.C. § 7409(b)(1) (2006); Lead Indus. Ass'n v. EPA, 647 F.2d 1130 (D.C. Cir. 1980). The war against lead pollution has not yet been won, however. See generally Richard L. Canfield et al., Intellectual Impairment in Children with Blood Lead Concentrations Below $10 \mu \mathrm{g}$ per Deciliter, 348 NEW ENG. J. MED. 1517 (2003).

13. See generally TiJs Goldschmidt, Darwin's DREAMPOND: DRAma IN LaKe Victoria (Sherry Marx-Macdonald trans.) (1996); Peter N. Reinthal \& George W. Kling, Exotic Species, Trophic Interactions, and Ecosystem Dynamics: A Case Study of Lake Victoria, in THEORY AND APPLICATION IN Fish FeEdING ECOLOGY 296 (Deanna J. Stouder et al. eds., 1994); Richard Ogutu-Ohwayo et al., Human Impacts on the African Great Lakes, 50 ENVTL. BIOL. FISHES 117 (1997). 


\section{Conservation Versus Exploitation}

Another great ethical divide separates entire branches of law and the life sciences. Does the primary value of living things subsist in their commercial potential, or should the biosphere's symbolic and aesthetic value take precedence?

This debate is perhaps most familiar within ecolaw, particularly debates over the protection of endangered species and critical habitats. It is easily translated to issues that sound more naturally of anthropolaw, especially to the extent that Moore v. Regents of the University of California ${ }^{14}$ highlights a more prevalent problem involving the exploitation of human genes, cell cultures, and organs. Most observers, however, encounter the problem of conservation vis-à-vis exploitation in the context of debates over distinctly useless and uncharismatic organisms such as the Delhi Sands flower-loving fly. ${ }^{15}$

Environmental ethicist Mark Sagoff has consistently posed the stiffest challenge to strictly utilitarian defenses of biodiversity conservation. "[N]o plausible scientific argument at present supports the claim that the extinction of species ... courts environmental disaster,", he writes. "It is far more plausible that rare and endangered species [are] affected by the environment but hav[e] little effect upon it." ${ }^{17}$ Having established what is, for most analysts of environmental policy, an extreme position rejecting all "instrumental or economic rationale[s]"18 for the protection of endangered species, Sagoff proceeds to defend aggressive protection of species, habitats, landscapes, and ecosystems on "[m]oral, aesthetics, and spiritual arguments."19

14. 793 P.2d 479 (Cal. 1990).

15. See Nat'l Ass'n of Home Builders v. Babbitt, 130 F.3d 1041, 1043 (D.C. Cir. 1997); Bradford C. Mank, Protecting Intrastate Threatened Species: Does the Endangered Species Act Encroach on Traditional State Authority and Exceed the Outer Limits of the Commerce Clause?, 36 GA. L. REV. 723, 754-64 (2002); John Copeland Nagle, The Commerce Clause Meets the Delhi Sands Flower-Loving Fly, 97 Mich. L. ReV. 174, 179 (1998); Omar N. White, The Endangered Species Act's Precarious Perch: A Constitutional Analysis Under the Commerce Clause and the Treaty Power, 27 ECology L.Q. 215, 216-21 (2000).

16. Mark Sagoff, Muddle or Muddle Through? Takings Jurisprudence Meets the Endangered Species Act, 38 WM. \& MARY L. REV. 825, 844 (1997) [hereinafter Sagoff, Muddle]. For an older but still instructive survey of utilitarian rationales in environmental law, see Mark Sagoff, Economic Theory and Environmental Law, 79 MiCH. L. REV. 1393 (1981).

17. Sagoff, Muddle, supra note 16, at 844.

18. Id.

19. Id. 


\section{Greens Versus Browns}

Environmental law again illustrates another difference in perspectives within biolaw. Are biological problems demanding legal solutions more fruitfully analyzed from a "brown" pollution-control paradigm, or from a "green" perspective stressing the removal or (better yet) prevention of a perceptible human footprint on the biosphere? Entire bodies of law fall on one side or the other of this divide. Pollution control feels very different from endangered species protection, and for that reason a "green" law school course on natural resources law (as distinct from a broader survey course on environmental law) more readily accommodates a segment on the Endangered Species Act than one on the Clean Water Act.

Again, though, this dichotomy cuts more subtly within subdisciplines connecting law with the life sciences. Consider one of the most ambitious legal applications of conservation biology: the hope that environmental law might facilitate the restoration of ecosystems compromised by human activity. ${ }^{20}$ Ecosystem restoration is typically defined as "the return of an ecosystem to a close approximation of its condition prior to disturbance." 21 More aggressive definitions of restoration as "the process of repairing damage caused by humans to the diversity and dynamics of indigenous ecosystems" lay explicit blame at human feet. ${ }^{22}$ By contrast, in a creative twist on a challenge conventionally regarded as a "green" problem of minimizing human footprints, Alyson Flournoy approaches ecosystem restoration as if it were a medical project. She describes ecosystems as "sick," thanks to numerous pathologies attributable to human activity. ${ }^{23}$ From this perspective, environmental policymakers should seek to diagnose the illness and to prescribe an appropriate cure as if impaired ecosystems were human patients.

I hasten to add that different approaches to conservation biology have made little or no legal difference. Federal courts routinely decline to treat conservation biology as "a necessary element of diversity analysis" under federal forest management statutes. ${ }^{24}$ For instance, the Seventh Circuit has held that uncertainties surrounding the application of "population

20. See generally A. Dan Tarlock, Slouching Toward Eden: The Eco-Pragmatic Challenges of Ecosystem Revival, 87 MiNN. L. REV. 1173 (2003).

21. National Research Council, Restoration of AQuatic Ecosystems 18 (Susan Maurizi \& Florence Poillon eds. 1992).

22. Laura L. Jackson et al., Ecological Restoration: A Definition and Comments, 3 RESTORATION ECOLOGY 71, 71 (1995).

23. See Alyson C. Flournoy, Restoration Rx: An Evaluation and Prescription, 42 ARIZ. L. REV. 187, 188 (2000) (drawing "on metaphors from medicine" in order to "sketch out ... 'a prescription"”).

24. Sierra Club v. Marita, 46 F.3d 606, 620 (7th Cir. 1995). 
dynamics, species turnover, patch size, recolonization problems, fragmentation problems, edge effects, and island biogeography" permitted the U.S. Forest Service to ignore these principles of conservation biology. ${ }^{25}$ Even a valid "general theory," that court held, "does not translate into a management tool unless one can apply it to a concrete situation." 26 Similarly, a federal district court has declined to require the Fish and Wildlife Service to adopt specific techniques for managing "distinct geographic ecosystems... inhabited by grizzly bears."27 The court reasoned that science or circumstances might change and thereby undermine the claim that the Endangered Species Act requires the Fish and Wildlife Service to establish linkage zones between ecosystems inhabited by grizzlies. ${ }^{28}$

\section{E. Conventional Versus Transgenic Biotechnology}

Finally, within specific areas of biolaw that deal with the development, ownership, and deployment of biological technology, a sharp distinction separates conventional technology from transgenic techniques. Although humans have modified the genetic destiny of other organisms since the dawn of agriculture and animal husbandry, the ability to manipulate genes without regard to "natural" reproduction has raised an extremely large set of legal issues.

Biotechnology in its broadest sense views " $[\mathrm{t}]$ he living world ... as a vast organic Lego kit inviting combination, hybridisation, and continual rebuilding." " Under the Convention on Biological Diversity, "'biotechnology' means any technological application that uses biological systems, living organisms, or derivatives thereof, to make or modify products or processes for specific use."30 In common parlance, "biotechnology" carries a comparably broad connotation, embracing any "means or way of manipulating life forms ... to provide desirable products for [human] use." 31 Although "beekeeping and cattle breeding could be considered to be biotechnology-related endeavors," the term

25. Id. at $618-21$.

26. Id. at 623 .

27. Fund for Animals v. Babbitt, 903 F. Supp. 96, 106 (D.D.C. 1995).

28. Id. at $107-10$.

29. Edward Yoxen, The Gene Business: Who Should Control Biotechnology? 15 (1983).

30. United Nations Conference on Environment and Development: Convention on Biological Diversity, art. 2, June 5, 1992, 31 I.L.M. 818, 823; see also id. at 824 (“"Technology' includes biotechnology.").

31. Kimball R. Nill, Glossary of BiotechnOlOgy Terms 30 (Technomic 2d ed. 1998). 
"biotechnology" as used "in the United States has come to mean all parts of an industry that knowingly create, develop, and market a variety of products through the willful manipulation, on a molecular level, of life forms or utilization of knowledge pertaining to living systems." ${ }^{32}$ Consequently, most legal discussions narrowly define biotechnology as the use of "new technologies [such] as recombinant DNA techniques (also called genetic engineering), cell culture, and monoclonal antibody (hybridoma) methods ... 'to make or modify products, to improve plants or animals, or to develop microorganisms for specific uses."

The ownership and use of biotechnology give rise to distinct concerns and consequently to distinct bodies of law. Domestic law typically treats the ownership of biotechnology as a question of intellectual property. Under American law, for instance, plant breeders can protect their work through patents, ${ }^{34}$ plant patents, ${ }^{35}$ plant variety protection certificates, ${ }^{36}$ and even copyrights. ${ }^{37}$ Notwithstanding the negative posture of the Copyright Office, ${ }^{38}$ nucleic acid sequences and even complex life forms may qualify for protection under the copyright laws. ${ }^{39}$ The trade secret laws of the

32. Id. at $30-31$.

33. U.S. Congress, Office of Technology Assessment, A New ERA for American Agriculture 65 (1992). See generally Dan L. Burk, Introduction: A Biotechnology Primer, 55 U. PITT. L. REV. 611 (1994).

34. See Patent Act of 1952, § 1, 35 U.S.C. $§ 101$ (2006); J.E.M. Ag. Supply, Inc. v. Pioneer HiBred Int'l, Inc., 534 U.S. 124, $144-45$ (2001); Diamond v. Chakrabarty, 447 U.S. 303, 308-09 (1980); Ex parte Hibberd, 227 U.S.P.Q. 443 (1985); cf. In re Kratz, 592 F.2d 1169, 1174-75 (C.C.P.A. 1979) (holding that a compound purified from strawberries can be patented even though a nonpurified form of that compound exists in strawberries).

35. See Plant Patent Act of 1930, 35 U.S.C. $§ \S 161-164$ (2000); Yoder Bros., Inc. v. CaliforniaFlorida Plant Corp., 537 F.2d 1347 (5th Cir. 1976) (holding that the chrysanthemum patents were valid and infringed); Pan-Am. Plant Co. v. Matsui, 433 F. Supp. 693 (N.D. Cal. 1977) (finding that the yellow mutation of the variety "May Shoesmith" chrysanthemum was substantially different from the plaintiff's patented plant).

36. See Plant Variety Protection Act of 1970, 7 U.S.C. $\$ \S 2321-2582$ (2000); Asgrow Seed Co. v. Winterboer, 513 U.S. 179 (1995); Imazio Nursery, Inc. v. Dania Greenhouses, 69 F.3d 1560 (Fed. Cir. 1995).

37. For a nonlawyer's survey of intellectual property in agricultural inventions, see INTELLECTUAL Property Rights in Agricultural Biotechnology (F. H. Erbisch \& K. M. Maredia eds., CAB International $2 \mathrm{~d}$ ed. 2004)

38. See Office of TeChnology Assessment, U.S. Congress, Publ'n No. OTA-BA-370, New Developments in Biotechnology: PAtenting Life-Special Report 43 (1989) (noting the Copyright Office's unofficial position that nucleic acid sequences are not copyrightable); $c f .2$ IVER P. COOPER, BIOTECHNOLOGY AND THE LAW $§ 11.2$ (2007) (disputing the copyrightability of nucleic acid sequences).

39. See generally Dan L. Burk, Copyrightability of Recombinant DNA Sequences, 29 JURIMETRICS J. 469 (1989); Irving Kayton, Copyright in Living Genetically Engineered Works, 50 GeO. WASH. L. REV. 191 (1982); Doreen M. Hogle, Comment, Copyright for Innovative Biotechnological Research: An Attractive Alternative to Patent or Trade Secret Protection, 5 HIGH TeCH. L.J. 75 (1990); Donna Smith, Comment, Copyright Protection for the Intellectual Property Rights to Recombinant Deoxyribonucleic Acid: A Proposal, 19 ST. MARY's L.J. 1083 (1988). 
states can provide additional protection for certain hybrid crops. ${ }^{40}$ Microorganisms have been patentable for more than a quarter century. ${ }^{41}$ Since 1988 the Patent and Trademark Office (PTO) has routinely granted utility patents for transgenic animals. ${ }^{42}$ The PTO also awards patents for "isolated and purified gene composition[s]" as long as the inventor "discloses a specific, substantial, and credible utility."43 Proprietary treatment seems to be the fate of large chunks of the human genome. ${ }^{44}$ The story of the first generation of biotechnological inventors as legal entrepreneurs leaves no doubt: ${ }^{45}$ human beings invent other living things, ${ }^{46}$ and the law rewards those who invent living things on par with other inventors.

Regulating the use of biotechnology, by contrast, is a vastly messier affair. In the United States, for example, the Environmental Protection Agency, the Department of Agriculture, and the Food and Drug Administration share regulatory responsibility. ${ }^{47}$ Since 1992 , questions of

40. See, e.g., Pioneer Hi-Bred Int'l, Inc. v. Holden Found. Seeds, Inc., 35 F.3d 1226, 1236-37 (8th Cir. 1994) (holding that the genetic messages of certain corn seed were trade secrets).

41. Diamond v. Chakrabarty, 447 U.S. 303, 309-10 (1980).

42. See, e.g., Transgenic Non-Human Mammals, U.S. Patent No. 4,736,866 (filed June 22, 1984) (issued April 12, 1988); see also Policy on Patenting of Animals, 1077 Official Gaz. Pat. Off. 24 (1987) (outlining procedures for animal patents); Rebecca Dresser, Ethical and Legal Issues in Patenting New Animal Life, 28 Jurimetrics J. 399 (1988); Robert P. Merges, Intellectual Property in Higher Life Forms: The Patent System and Controversial Technologies, 47 MD. L. REV. 1051 (1988); Thomas Traian Moga, Transgenic Animals as Intellectual Property (or the Patented Mouse That Roared), $76 \mathrm{~J}$. Pat. \& TRademark OfF. SoC'Y 511 (1994); Kevin W. O'Connor, Patenting Animals and Other Living Things, 65 S. CAL. L. Rev. 597 (1991); Paul Blunt, Note, Selective Breeding and the Patenting of Living Organisms, 48 SYRACUSE L. REV. 1365 (1998).

43. United States Patent and Trademark Office, Utility Examination Guidelines, 66 Fed. Reg. 1092, 1093 (Dep't of Commerce Jan. 5, 2001). See generally John J. Doll, The Patenting of DNA, 280 SCIENCE 689 (1998) (discussing concern within the biotechnology community over DNA patents); Michelle R. Henry et al., DNA Patenting and Licensing, 297 SCIENCE 1279 (2002); Daniel Kevles \& Ari Berkowitz, The Gene Patenting Controversy: A Convergence of Law, Economic Interests and Ethics, 67 BROOK. L. REV. 233 (2001).

44. See generally Perspectives on Properties of the Human Genome Project (F. Scott Kieff \& John M. Olin eds., 2003).

45. For the story of how inventors such as Ananda Chakrabarty, Standish Allen, Kenneth Hibberd, Philip Leder, and Timothy A. Stewart not only advanced the life sciences but also spurred epochal change in the law of intellectual property, see Daniel J. Kevles, Ananda Chakrabarty Wins a Patent: Biotechnology, Law, and Society, 1972-1980, 25 Hist. STUD. IN PHYS. \& BIOL. ScIS. 111 (1994); Daniel J. Kevles, Diamond v. Chakrabarty and Beyond: The Political Economy of Patenting Life, in PRIVATE SCIENCE: BIOTEChNOlOGY AND THE RISE OF THE MOleCUlar SCIENCES 65 (Arnold Thackray ed., 1998).

46. See Mildred K. Cho et al., Ethical Considerations in Synthesizing a Minimal Genome, 286 SCIENCE 2087, 2087 (1999) (discussing "[e]fforts to create a free-living organism with a minimal genome").

47. See generally Office of Science \& Technology Policy, Coordinated Framework for Regulation of Biotechnology, 50 Fed. Reg. 47,174 (Nov. 14, 1985) (setting forth a "regulatory matrix" that outlines the patchwork of laws and agencies governing the use of biotechnology in the United States). 
biotechnology use have overshadowed questions of ownership. European resistance to transgenic crops, ${ }^{48}$ not to mention the violent protests against the World Trade Organization's 1999 meeting in Seattle, ${ }^{49}$ helped shift the spotlight. As a general rule, the American law of intellectual property defers all questions of consumer safety, environmental protection, and morality to other legal schemes. ${ }^{50}$

Perhaps the most succinct way of summarizing this distinction lies in vocabulary. Conventional biotechnology-biological concepts and breeding techniques associated with Charles Darwin, Gregor Mendel, Luther Burbank, and Norman Borlaug - speaks in the Greco-Latin terms associated with the Linnaean taxonomy of living things. Transgenic techniques, by contrast, are described with vaguely corporate and definitely threatening acronyms such as GMO (genetically modified organism) and rbST (recombinant bovine somatotropin). From PCR (polymerase chain reaction) to RNAi (ribonucleic acid interference), "new" biotechnology poses a linguistically and emotionally daunting challenge to the law. By contrast, even the name Yersinia pestis - the bacterium responsible for bubonic plague ${ }^{51}$ — sounds downright romantic.

Having defined biolaw, I will now explain why it matters.

48. See generally, e.g., Thomas Bernauer, Genes, Trade, and Regulation: The SeEds of Conflict IN Food Biotechnology (2003); Marsha A. Echols, Food Safety Regulation in the European Union and the United States: Different Cultures, Different Laws, 4 Colum. J. EuR. L. 525 (1998); Sophia Kolehmainen, Precaution Before Profits: An Overview of Issues in Genetically Engineered Food and Crops, 20 VA. EnVTL. L.J. 267 (2001); John Charles Kunich, Mother Frankenstein, Doctor Nature, and the Environmental Law of Genetic Engineering, 74 S. CAL. L. REV. 807 (2001); Paul Raeburn, Clamor over Genetically Modified Foods Comes to the United States, 8 N.Y.U. ENVTL. L.J. 610 (2000); Terence P. Stewart \& David S. Johanson, Policy in Flux: The European Union's Laws on Agricultural Biotechnology and Their Effects on International Trade, 4 DRAKE J. AGRIC. L. 243 (1999); Jeffrey K. Francer, Note, Frankenstein Foods or Flavor Savers?: Regulating Agricultural Biotechnology in the United States and European Union, 7 VA. J. SOC. POL'Y \& L. 257 (2000).

49. See, e.g., Gerard Baker, Starbucks Wars, FIN. TIMES, Dec. 4, 1999, at 10 (describing the protests as "America's first post-modern riot"); see also Jim Chen, Pax Mercatoria: Globalization as a Second Chance at "Peace for Our Time," 24 FORDHAM INT'L L.J. 217, 219 (2000) (discussing the legal significance of the Seattle riots); John W. Head, Throwing Eggs at Windows: Legal and Institutional Globalization in the 21st-Century Economy, 50 U. KAN. L. REV. 731, 735 (2002) (same).

50. See generally Margo A. Bagley, Patent First, Ask Questions Later: Morality and Biotechnology in Patent Law, 45 WM. \& MARY L. REV. 469 (2003).

51. See generally B. Joseph Hinnebusch et al., Role of Yersinia Murine Toxin in Survival of Yersinia pestis in the Midgut of the Flea Vector, 296 SCIENCE 733 (2002); Mark Achtman et al., Yersinia pestis, the Cause of Plague, Is a Recently Emerged Clone of Yersinia pseudotuberculosis, 96 PROC. NAT'L ACAD. SCI. 14,043 (1999). 


\section{Biolaw AS A Mediator AmONG THREe InTELlECtUAL CUltures}

The challenge of defining biolaw represents one small facet of a social problem that has long bedeviled science and the broader culture. Biolaw straddles the crucial, hotly contested point where the distinct and often antagonistic cultures of literature and the arts, the natural sciences, and the social sciences collide. In his celebrated lecture, The Two Cultures, C.P. Snow excoriated the conflict between what he called the scientific and literary cultures. Snow aimed his sharpest criticism for "natural Luddites," the "[W]estern intellectuals [who] have never tried, wanted, or been able to understand the industrial revolution, much less accept it." 52 The dominant literary culture's refusal to embrace science and its industrial applications, said Snow, condemned humanity's humblest to a wretched, short existence: ${ }^{.3}$

Most of our fellow human beings ... are underfed and die before their time. In the crudest terms, that is the social condition. There is a moral trap which comes through the insight into man's loneliness: it tempts one to sit back, complacent in one's unique tragedy, and let the others go without a meal. ${ }^{54}$

In a world "where cultural antipathies are very much alive and kicking," The Two Cultures still resonates. ${ }^{55}$ Deep, even catastrophic, cultural divides cripple public understanding of a wide range of scientifically sophisticated issues, from global climate change and biodiversity loss to childhood vaccination, embryonic stem cell research, contraception, abortion, and end-of-life decisionmaking.

Crudely stated, biolaw's mission is that of bridging the scientific and literary cultures that Snow found so lamentably divided in 1959. By virtue of their training, scientifically literate lawyers and legal scholars owe a special duty to ply the intellectual tools unique to what Snow perceived vaguely as something like "a third culture," a community of social scientists "concerned with how human beings are living or have lived." Anyone who would live contemporary life in its immense fullness and complexity must master not only the scientific culture's "basic facts" and "guiding

52. C.P. Snow, The Two Cultures: And A Second Look 22 (2d ed. 1965).

53. THOMAS HOBBes, LEviATHAN 89 (Richard Tuck ed., 1996) (describing life as "solitary, poore, nasty, brutish, and short").

54. SNOW, supra note 52, at 6-7.

55. Cultural Divides, Forty Years On, 398 NATURE 91 (1999).

56. SNOW, supra note 52, at 70. 
principles of quantitative thought and strict logic," but also the literary culture's "canon of works and expressive techniques." ${ }^{\text {, }}$ Ever since it became impossible to speak of law without appending the conjunction $a_{n d}{ }^{58}$ or at least since legal scholars stopped thinking of law as an autonomous discipline, ${ }^{59}$ law has stood at the center of the "third culture" of the social sciences. At their best, social sciences such as law, economics, and positive political theory bridge the scientific and literary cultures, much as Snow himself, as a scientist, novelist, and public administrator, traversed all three of contemporary civilization's intellectual subcultures.

The law's access to the literary culture enables biolaw to achieve social goals, especially by political means, that natural scientists often find frustratingly beyond their reach. Law represents nothing more and nothing less than "the enterprise of subjecting human conduct to the governance of rules." 60 That project, no less than any exercise in economic problemsolving, "must ultimately dissolve into a study of aesthetics and morals." This very source of strength, however, represents the law's deepest intellectual weakness. Legally trained professionals face formidable barriers to escaping the deepest intellectual traps of the literary culture. Perhaps the starkest contrast between the scientific and literary cultures of C.P. Snow's celebrated lecture appears in these two cultures' regard for the past. Whereas a "science which hesitates to forget its founders is lost," the literary culture reserves its highest regard for "giants in the earth" in days "of old," in days "of renown." 63 The literary culture reveres founders; the scientific culture fosters forgetters. To the extent that the law yearns for ancient, even legendary, inspiration, it favors the literary culture in the war of values that Snow decried.

Worse still, the law shares other literary disciplines' instinctive response to the natural world's frightening "scarcity of rhyme and reason"

57. Frank Wilczek, The Third Culture, 424 NATURE 997, 997 (2003).

58. See generally Arthur Allen Leff, Law and, 87 YALE L.J. 989 (1978).

59. See generally Richard A. Posner, The Decline of Law as an Autonomous Discipline: 19621987, 100 HARV. L. REV. 761 (1987).

60. LON L. FULLER, THE MORALITY OF LAW 122 (rev. ed. 1969) (13th prtg. 1976).

61. R.H. Coase, The Problem of Social Cost, 3 J.L. \& ECON. 1, 43 (1960).

62. A. N. WhITEHEAD, THE AIMS OF EDUCATION \& OTHER ESSAYS 162 (1929); see also WiLSON, supra note 1, at 182-83 ("[P]rogress in a scientific discipline can be measured by how quickly its founders are forgotten."); $c f$. J.E. LOVELOCK, GAIA: A NEW LOOK AT LIFE ON EARTH 70 (1979) ("It is somewhat cynically said that the eminence of a scientist is measured by the length of time that he holds up progress in his field."). On collective memory and oral tradition in science, see generally Commemorative Practices in Science: Historical Perspectives on the Politics of Collective Memory (Pnina G. Abir-Am \& Clark A. Elliot eds., 2000); Bruno J. Strasser, Who Cares About the Double Helix?, 422 NATURE 803 (2003).

63. Genesis 5:4 (King James Version). 
by imposing, "even on random facts and chance phenomena, artificial order based on false principles of causation." 64 The resulting "illusion of predictability and even of mastery" gives rise to the fantasy "we can manipulate the world around us by appealing to the imaginary forces we have invented." ${ }^{65}$ As a result, lawyers as a class seem as prone to the fundamental fallacy of creationism - the mirage of anthropomorphic agency - as the layperson or (worse still) the elected official who rejects the central historic narrative of evolutionary biology: life on this ancient earth of ours is shaped by forces no more mysterious than random mutation, natural and sexual selection, adaptive radiation, evolutionary convergence, and the occasional meteor strike.

Among leading "caricatures" that well-intentioned observers use to describe nature and other complex systems, the predominant view of law is that of a complex system "existing at or near an equilibrium condition." Conventional depictions of the law treat time neither as "a gulf to be bridged" nor as "a yawning abyss," but rather as a medium "filled with the continuity of custom and tradition, in the light of which all that is handed down presents itself to us." ${ }^{\text {"67 }}$ Colloquial uses of "law" in other fields, such as Grimm's law, ${ }^{68}$ the third law of thermodynamics, or Zipf's law, ${ }^{69}$ all treat "laws" as immanent, enduring principles that govern natural phenomena. These descriptions of law-in its literal sense as a system of governance and in the figurative sense suggested by the language of science - obscure the role of sudden, even catastrophic change in legal evolution. "In biological terms, stasis is death; only growth and change keep the organism alive."70 To ensure that its "ideas and aspirations ... survive more ages than one," the law must respond to upheaval. ${ }^{71}$

64. Murray Gell-Mann, The QuARK AND the Jaguar: AdVENTURES In THE Simple AND THE COMPLEX 276 (1994).

65. Id.

66. C.S. Holling, Lance H. Gunderson, \& Donald Ludwig, In Quest of a Theory of Adaptive Change, in PANARCHY: UNDERSTANDING TRANSFORMATIONS IN HUMAN AND NATURAL SYSTEMS 3 , 12 (Lance H. Gunderson \& C.S. Holling eds., 2002).

67. Hans-Georg Gadamer, Truth AND Method 264-65 (Garrett Barden \& John Cumming trans. 1975). See generally William N. Eskridge, Jr., Gadamer/Statutory Interpretation, 90 CoLUM. L. REV. 609 (1990).

68. See Louis HJelmsleV, LANGUAGE 128-29 (Francis J. Whitfield trans. 1970) (describing how phonological principles such as Grimm's Law or Verner's Law become so entrenched in a particular language that they become "law[s] of state" rather than "law[s] of change").

69. See George Kingsley Zipf, Human Behavior and the Principle of Least EFfort: AN INTRODUCTION TO HUMAN ECOLOGY (1949) (describing the distribution of words in natural languages); GeORGE KingSlEy ZIPF, SELECTIVE StUdies OF THE PRINCIPLE OF RELATIVE FrEQUENCY IN LANGUAGE (1932) (same).

70. Marci A. Hamilton, Art Speech, 49 VAND. L. REV. 73, 76 (1996).

71. Planned Parenthood v. Casey, 505 U.S. 833, 901 (1992); $c f$. U.S. ConsT. pmbl. (describing the Constitution as having been adopted "in Order to ... secure the Blessings of Liberty to ourselves and 
Judicially and politically negotiated equilibria in $\operatorname{law}^{72}$ are episodic at best and prone to violent interruption. ${ }^{73}$ The so-called jurisdynamics of human governance $^{74}$ reflects a sort of "punctuated equilibrium," reminiscent of Stephen Jay Gould's description of biological evolution. ${ }^{75}$

Even within the scientific culture, disciplinary divides persist. Scientists are trying to bridge the "curious lack of communication between molecular biologists and the mathematicians and electrical engineers who developed information theory and coding theory." 76 Treating biology as a branch of information science naturally and effectively connects those disciplines. Code, whether it is expressed in binary digits or in the ATCG alphabet of molecular biology, ${ }^{77}$ is code. ${ }^{78}$ Having long "conceive[d] of genetic information and electronic information as information," we now "have the technical capability to make good on this conception."79 Gerald Edelman won the 1972 Nobel Prize in medicine for discovering how antibodies enabled the immune system to identify and remember patterns and thereby to attack invaders without harming itself. ${ }^{80}$ Seemingly simple

our Posterity"); see also McCulloch v. Maryland, 17 U.S. (4 Wheat.) 316, 41517 U.S. at 427 (1819) ("This provision is made in a constitution, intended to endure for ages to come, and consequently, to be adapted to the various crises of human affairs.").

72. See generally William N. Eskridge, Jr. \& Philip P. Frickey, The Supreme Court, 1993 TermForeword: Law as Equilibrium, 108 HARV. L. REV. 26 (1994).

73. See generally Daniel A. Farber, Earthquakes and Tremors in Statutory Interpretation: An Empirical Study of the Dynamics of Interpretation, 89 MINN. L. REV. 848 (2005) (discussing the problematic idea of "typical" statutory interpretation).

74. See generally The Jurisdynamics of EnVironmental Protection: Change AND the Pragmatic Voice in ENVIRONMENTAL LAW (Jim Chen ed., 2003).

75. Cf. Stephen Jay Gould, The PANDA's Thumb 149-54 (1980) (describing "the episodic nature of evolutionary change" as representative of "punctuated equilibria").

76. Hubert P. Yockey, Information TheORY and Molecular Biology xvii (1992). See generally John Holland, ADAPTATION IN NATURAL AND ARTIFICIAL SySTEMS (1975); MELANIE Mitchell, An Introduction to Genetic Algorithms (1996); Alan Hastings \& Margaret A. Palmer, A Bright Future for Biologists and Mathematicians?, 299 SCIENCE 2003 (2003).

77. Those letters represent the component bases of deoxyribonucleic acid: adenine, thymine, cytosine, and guanine. See, e.g., Maxine Singer \& Paul Berg, Genes And GenOmes: A Changing PERSPECTIVE 36-37 (1991). Adenine bonds only with thymine; cytosine, only with guanine. See Burk, supra note 33 , at $612-14$.

78. James Boyle, A Politics of Intellectual Property: Environmentalism for the Net?, 47 DuKE L.J. 87, 87-88 (1997) (describing this attitude as the heart of the "cyberpunk" ethos).

79. Id. at 91 (emphasis omitted).

80. Gerald M. Edelman, Bright Air, Brilliant Fire: On the Matter of the Mind 75 (1992):

The immune system is a somatic selective system consisting of molecules, cells, and specialized organs. As a system, it is capable of telling the difference between self and nonself at the molecular level. For example, it is responsible for distinguishing between and responding to the chemical characteristics of viral and bacterial invaders (nonself), invaders that would otherwise overwhelm the collections of cellular systems in an individual organism (self) .... An appropriately stimulated immune system can tell the 
organisms, real or virtual, have solved mazes and performed other complex pathfinding tasks. ${ }^{81}$

Bioinformatics represents merely one tendril of the scientific rhizome that has grown from the double helix. ${ }^{82}$ Computer scientists have experimented with DNA itself as a parallel processor. ${ }^{83}$ Professional taxonomy - the time-honored task of classifying all living things - is being transformed by an electronically driven revolution that harnesses the storage and search capacities of the Internet. ${ }^{84}$ The online Encyclopedia of Life intends "to document all species of life on Earth" by maintaining a "constantly evolving encyclopedia that lives on the Internet, with contributions from scientists and amateurs alike."

At any level-evolutionary, ecological, organismal, physiological, cellular, or molecular ${ }^{86}$ - biology is displaying the "emergent behavior" of "complex adaptive systems." ${ }^{87}$ Just as the novel term lex informatica describes the deployment of technological constraints on electronic

difference between two large foreign protein molecules composed of thousands of carbon

atoms that differ by only a few degrees in the tilt of a single carbon chain.

See generally Gerald M. EdELMAN, TOPOBIOLOGY: AN INTRODUCTION to MOLECUlaR EMBRYOLOGY (1988). For succinct primers on immunology, see JACQUELYN G. BLACK, Microbiology: Principles AND APPLiCATIONS 473-507 (2d ed. 1993); NeIL A. CAMPBell, BIOLOGY 850-72 (3d ed. 1993). For an application of immunological principles to constitutional law, see Gil Grantmore, The Phages of American Law, 36 U.C. DAVIS L. REV. 455, $492-97$ (2003).

81. Compare Toshiyuki Nakagaki, Hiroyasu Yamada \& Ágota Tóth, Maze-Solving by an Amoeboid Organism, 407 NATURE 470 (2000) (reporting how slime mold, Physarum polycephalum, plotted the shortest possible path between two food sources in a maze), with Eric Bonabeau \& Guy Théraulaz, Swarm Smarts, SCI. AM., Mar. 2000, at 73 (reporting on Margo Dorigo's use of virtual ants, complete with electronic pheromones, to reach "near-optimal" solutions to the directed Hamiltonian path problem, popularly known as the traveling salesman problem).

82. See generally James D. Watson, The Double Helix: A Personal Account of the DisCovery OF THE STRUCTURE OF DNA (Reprint 2001) (1968); JAMES D. WATSON \& ANDREW BerRy, DNA: The SeCret of Life (2003); Robert Olby, The Path to the Double Helix (1974).

83. See David K. Gifford, On the Path to Computation with DNA, 266 SCIENCE 993 (1994) (describing the use of synthesized DNA strands to solve a simple version of the traveling salesman problem). See generally DAVID BERLINSKI, THE ADVENT OF THE ALgORITHM: THE IDEA THAT RULES THE WORLD 275-305 (2000); EVOluTIONARY COMPUTATION IN BIOINFORMATICS (Gary B. Fogel \& David W. Corne eds., (2003); Moshe SiPPer, Machine NATURE: The Coming Age OF Bio-INSPIRED COMPUTING (2002).

84. See, e.g., Frank A. Bisby et al., Taxonomy, at the Click of a Mouse, 418 NATURE 367 (2002); H. Charles J. Godfray, Challenges for Taxonomy, 417 NATURE 17 (2002); Michael S.Y. Lee, Online Database Could End Taxonomic Anarchy, 417 NATURE 787 (2002); David J. Patterson, Progressing Towards a Biological Names Register, 422 NATURE 661 (2003).

85. Encyclopedia of Life, http://www.eol.org (last visited Apr. 11, 2008).

86. Cf. Matt Ridley, The Red QueEn: SeX AND the Evolution of Human Nature 42 (1993) (observing that although a single biological phenomenon might prompt a molecular biologist, a geneticist, and an ecologist to ask different questions, all three might "be 'right' on different levels").

87. Stephen Johnson, EMERgence: The ConNected Lives of ANTS, Brains, Cities, AND SOFTWARE 18 (2001). See generally JOHN H. Holland, EMERgENCE: From ChaOS to ORDER (1998). 
information as a source of policy, ${ }^{88}$ the neologism lex genetica expresses the same idea with respect to bioengineered constraints on genetic information. ${ }^{89}$ In short, "information is information, whether the medium is a double helix or an optical disk." 90 Code, it bears repeating, is code. Mastery of biolaw holds the key to cracking that code.

The path of biolaw promises to be as diverse and as beautiful as all of the scientific, literary, artistic, and political domains that are governed by law and the life sciences. Best of all, it satisfies the indelible human instinct for beauty. Over the course of civilization, humanity has moved from using clever "observation and classification to document the subtle anatomy of flowers" to "the brink of answering ... more fundamental question[s]" having "more to do with patterns developing over time than with static structure." "91 Our numerous "attempt[s] to imitate the beautiful movements of Nature" represent significant, even spiritual, steps in the "development of [our] love of the beautiful." 92 The best scientific work has "always tried to unite the true with the beautiful." ${ }^{93}$ When the physicist Hermann Weyl "had to choose one or the other," however, he "usually chose the beautiful." 94 As John Keats expressed the point from the very heart of the literary culture, "'Beauty is truth, truth beauty,'- that is all / Ye know on earth, and all ye need to know." ${ }^{95}$

88. See Joel Reidenberg, Lex Informatica: The Formulation of Information Policy Rules Through Technology, 76 TEX. L. REV. 553 (1998).

89. See Dan L. Burk, Lex Genetica: The Law and Ethics of Programming Biological Code, 4 ETHICS \& INFO. TECH. 109 (2002).

90. Boyle, supra note 78 , at 92 .

91. JOHNSON, supra note 87, at 49.

92. NATHANiEl Hawthorne, The Artist of the Beautiful, in THE COMPLETE SHORT STORIES OF NATHANIEL HAWTHORNE 421, 423 (1959). See generally EDWARD O. WilsOn, BIOPHILIA (1984). 61.

93. Obituaries, 177 NATURE 457, 458 (1956) (quoting Weyl), quoted in WILSON, supra note 1, at

94. Id.

95. John KeAts, Ode on a Grecian Urn, in The COMPLETE PoEMs 344, 346 (John Barnard ed., 1973). 